\title{
Justification for Implementing Victim-Offender Mediation in the Criminal Justice System of Ghana.
}

\author{
Enoch Amoah'
}

${ }^{1}$ Faculty of Law, Kwame Nkrumah University of Science and Technology,Ghana.

\begin{abstract}
This study seeks to ascertain whether there are justifications for implementing Victim Offender Mediation (VOM) - a key Alternative Dispute Resolution (ADR) process capable of solving the shortcomings of the Criminal Justice Systems of Ghana. Doctrinal approach to legal research was deployed using qualitative research method in perusing and analysing provisions of the Courts Act 1993 Alternative Dispute Resolution Act 2010, Children's Act 1998, Domestic Violence Act 2007 and Juvenile Justice Act 2003. It also analysed literature on the use of ADR processes in criminal matters. It was found that the selected enactments with the exception of Domestic Violence Act 2007 provided justifications for implementing VOM in Ghana. The research also reveals that only offences in the categories of misdemeanor which are not aggravated in degree and offences regarded as minor offences can be referred for settlement by VOM. Further, criminal cases involving matters of public interest and those affecting the environment could not be resolved using VOM. It is recommended that the courts should take advantage of these findings to implement the use of VOM in resolving criminal cases in Ghana; the Judicial service should liaise with experts in VOM to provide training to judges and other stakeholders to enhance their capacities to implement VOM models in Ghana; and there should be sensitization of the public on the mechanics of VOM in resolving criminal cases so that a court will not appear to its audience as compromising the criminal justice system when it refers criminal cases for settlement by VOM.
\end{abstract}

Key words: Victim Offender Mediation, justification, implementation

(C) 2020 The Author(s). Published and Maintained by Noyam Publishers.

This is an open access article under the CCBY license (http://creativecommons.org/licenses/by/4.0/).

\section{INTRODUCTION}

Ghana's criminal justice system like most justice delivery systems in the world has from time immemorial employed a criminal justice delivery system which is predominately retributive in nature. However, this Criminal Justice Delivery Approach is lacking in effectiveness and efficiency in curbing the commission of crimes as it has failed to cater for: the effects of crimes committed on the community and victims of the crime, the rate of commission of crimes, the rate of and the duration of custodial sentences, overcrowding in Ghanaian prisons, human rights abuses in the prisons, pressure on the limited prison facilities, the deplorable conditions of prisons, the wastefulness of convicts' productive lives in incarceration, and inadequate compensation to a convict for wrongful incarceration ${ }^{2}$.

Realising the prevalence of these shortcomings in Ghana's criminal justice delivery system, the AttorneyGeneral's Department in collaboration with the Ghana Police Service, Judicial Service of Ghana, Ghana Bar Association, Civil Society groups and Ghana Prisons Service rolled out a project known as Justice For All Programme in 2007 to decongest Ghanaian prisons. Through the programme, special courts sittings were set up to adjudicate upon cases involving remand prisoners in prisons throughout the country. The programme has seen many inmates discharged of the offences they were charged with whilst others have either been granted bail or sentenced. ${ }^{3}$

The Supreme Court of Ghana also acknowledged the existence of shortcomings in Ghana's Criminal Justice

Eric Asante v. The Republic, CRIMINAL APPEAL NO. J3/7/2013 (SC, 2017).

3 POS FOUNDATION, “Justice for all Programme for Remand Prisoners.” Accessed July 14, 2016. http://posfoundation.org/justice-for-all-programme-forremand-prisoners/. 
System particularly in relation to the lengthy prison sentences imposed on convicts which failed to deter people from committing crimes and further leaves the country with many more young people spending most of their productive lives behind bars. ${ }^{4}$ The courts have advocated for serious reforms of the Criminal Justice System to train convicts to become productive in life instead of being a burden to the state after their release. It proposed the introduction of community service, confiscation of asserts derived or generated from criminal acts as some alternatives to incarceration of convicts. ${ }^{5}$ Even though the Supreme Court of Ghana has given the red alert for a drastic over haul of the criminal justice system of Ghana ${ }^{6}$, the foregoing recommendation of the court is yet to be completely implemented.

Though these recommendations are yet to see the full light of the day, Ghana Prisons Service Council has embarked on interventions dubbed Project 'Effiase' aimed at creating awareness about prisons conditions and raising funds from corporate Ghana, institutions and individuals to improve the conditions of prisons with the aim of transforming these prisons into reforming centers. ${ }^{7}$

Justice Georgina Theodora Wood, former Chief Justice of Ghana, attempted to avert the problems associated with Ghana's criminal justices system through advocating for courts to deploy ADR processes in Ghana's justice delivery system on many platforms. ${ }^{8}$ In one of her calls on judges to address some of the challenges bedeviling the criminal justice system, she advocated for decongestion of Ghana's prisons by judges through sentencing imposed by judges. In one of her proposals as a solution to decongest prisons, she admonished judges to ensure that petty young offenders are not unnecessarily exposed to excessive sentencing. ${ }^{9}$

However, rolled out of the Justice For All Programme in 2007 to decongest Ghanaian prisons by Attorney General's Department in collaboration with Judicial Service of Ghana, Ghana Prisons Service and other stakeholders seem not to solve the problems associated with the criminal justice delivery system in Ghana.

As at 2015, of the forty-three (43) prisons in Ghana with authorized holding capacity of nine thousand eight hundred and seventy-five $(9,875)$, thirteen thousand seven hundred and sixty-four $(13,764)$ inmates - a percentage overcrowding of thirty-nine percent (39.38\%) - were been held in the prisons. ${ }^{10}$ Of these inmates, eleven thousand nine hundred and twelve $(11,912)$ are convicts whilst one thousand eight hundred and fifty-two $(1,852)$ are not convicted prisoners. ${ }^{11}$ The overcrowding situation in Ghana's prisons is still a challenge owing to the fact that whilst the Justice for All Programme is expediting the release of innocent persons from incarceration, the courts are handing more convicts custodial sentences for crimes they committed. Concerns about the inability of the Justice for All Programme to serve the purpose of criminal justice in Ghana was expressed by Her Ladyship Chief Justice Georgina Theodora Wood (as she then was) and she called for a reform of its operations. She was also skeptical about the possibility of solving human right abuses arising out of congestions in these prisons through Project Effiase. ${ }^{12}$

The criminal justice system also is also unable to cater for the impact of crimes on victims and the communities in which the crimes were committed, reduce costs associated with the practice of imprisonment, curb or deter further commission of crimes, completely decongest prisons, eliminate all forms of human right abuses in the prisons, release convicts who have appealed on their convictions but are still in prison custody, reform convicts who are serving their sentence in incarceration, release all innocent persons and offenders on remand through an expedite retributive process known as Justice for All Programme for the courts.

The existing legislative framework for criminal justice delivery in Ghana is complemented by the Alternative Dispute Resolution Act (ADR) Act 2010 (Act 798) to expedite the justice delivery in Ghana. With this ADR process already at the courts' disposal, it was expected that Ghana's criminal justice system should not be fraught with the challenges it is currently saddled.

Calls by Justice Georgina Wood for Judges to deploy ADR processes in the justice delivery in Ghana are suggestive of the fact that ADR processes have the potential of serving as the right tools for solving most problems bedeviling Ghana's criminal justices system. It is worth noting that the calls to deploy ADR processes in the justice delivery in Ghana also suggest that the courts and other stakeholders in the criminal justice system of Ghana permit little or no recourse to ADR processes in resolving criminal cases that come before them. Victim-Offender Mediation (VOM),

\footnotetext{
Frimpong@Iboman v. Republic [2013] 42 M.L.R. $1 @ 29$.

Ibid 30 .

Ibid.

Emmanuel Agyemfra, 'Ghana Prisons Service Council unveils 2015/2016 Annual Report on Project Efiase', Ghana Web. September 6, 2016. Accessed November 11, 2017. https://mobile.ghanaweb.com/GhanaHomePage/regional/Ghana-Prisons-Service-Council-unveils-2015-2016-Annual-Report-onProject -Effiase-467743

8 GNA, “CJ Charge Judges to Ensure Quality Justice Delivery”, October 04, 2012, Ghana News Agency. Accessed July 1, 2017. https://www.google.com.gh/amp/www. ghananewsagency.org/human-interest/cj-charges-judges-to-ensure-quality-delivery-50135-1m0.html.

9 Marian Efe Ansah, "Help Decongest Prisons-CJ to Judges." Citifmonline.Com. February 23, 2015. Accessed July 01,2017. http://citifmonline.com/2015/02/23/ help-decongest-prisons-cj-to-judges/\#sthash.wV51iCOp.dpuf

10 Ghana Prisons Service, "Inmate Statistics". Accessed November 11, 2017. www.ghanaprisons.gov.gh/statistics.html

Ibid.

2 Ansah, "Help Decongest Prisons-CJ to Judges."
} 
an ADR process used in other jurisdictions to resolve criminal cases of any degree has proven to be very effective in achieving desirable results capable of resolving most of the problems identified as bedeviling Ghana's Criminal Justice System. ${ }^{13}$ However the successful implementation of VOM in the Ghana's criminal justice system depends on whether or not Ghana's legislative framework available permits its use. This article therefore seeks to peruse and analyse selected laws of Ghana and literature on deploying ADR mechanisms to resolve criminal cases in Ghana and ascertain whether there are justifications for implementing the use of VOM in the criminal justice system of Ghana.

\section{Conceptual framework}

The conceptual framework which grounds this research is the concept of Victim-Offender Mediation (VOM) as to prosecution of criminal cases in the Ghana's criminal justice system. VOM has been defined as "an alternative dispute resolution process involving a face to face meeting of the victim of a crime and offender charged with the crime in the presence of a mediator so as to resolve dispute between the offender and the victim of the crime to arrive at a consensus." ${ }^{\prime 4}$

It has also be defined as a process in which victims of primarily property crimes and minor assaults are given the opportunity to meet perpetrators of previous crimes they involved themselves in. ${ }^{15}$ The foregoing settlement process involves holding the offender directly accountable for the offence committed as well as providing assistance and compensation to the victim. ${ }^{16}$

From the above definitions, it may be deduced that Victim-Offender Mediation is a mediation process deployed to resolve a criminal case with the assistance of an expert who acts as the mediator between the offender and persons affected by the crime (victims) with the aim of repairing injuries caused to victims of crimes. This enables victims of crimes to fully participate in the dispute settlement process in response to the effects of the crimes perpetrated against them. It also ensures offenders of crimes are accountable for the offences committed.

\section{Origin of Victim-Offender Mediation}

Canada is regarded as the origin of the Victim-Offender Mediation. ${ }^{17}$ The city of Kitchener in Southern Ontario, Canada, has been named as the place where Victim-Offender Mediation was first used in resolving criminal cases. ${ }^{18}$ Anabaptist communities in Canada known as the Mennonite Communities were credited with the use of Victim-Offender Mediation as a mediation framework as far back as 1974. This framework has since seen the development of various models deployed in many communities worldwide. The development of these models is said to have spread worldwide because of the flexibility with which Victim-offender Mediation process could be adapted to any cultural setting for settlement of criminal cases. ${ }^{19}$

\section{Merits of Victim-Offender Mediation in Dispute Resolution}

In the past, most minor offences involving minor assaults and property crimes were admitted for resolution under Victim-Offender Mediation (VOM) in some jurisdictions. ${ }^{20}$ However, with the successes chalked by the use of VictimOffender Mediation programs, these programs have been extended to resolve more serious and violent crimes like murder, attempted homicide, rape and vehicular homicide in some jurisdictions. ${ }^{21}$ The use of the VOM in resolving criminal cases is said to have several advantages over prosecuting criminal cases through the court system. There are also identified disadvantages associated with the use of VOM in resolving criminal cases. This subsection is dedicated to looking at the advantages of using VOM in resolving criminal cases.

VOM increases victims' satisfaction in prosecuting criminal cases. ${ }^{22}$ Unlike prosecution of criminal cases in the court where victims of crimes are often relegated to the back bench depriving victims the opportunity to fully participate in criminal trials, Victim-Offender mediation employed in settling criminal cases provides victims and

\footnotetext{
13 Jessica C. Ames Restorative Justice: Including Victims, Offenders and Communities in Criminal Justice Dialogue (2007, Smith College).

14 Ibid.

15 Mark Umbreit, "Victim-Offender Mediation and Dialogue" in Dialogue-Driven Victim-Offender Mediation Training Manual A Composite Collection of Training Resource Materials.

16 Ibid.

17 Carmel Benjamin, A.M. Victoria, "Why is Victim/Offender Mediation Called Restorative Justice?" (a paper presented at the Restoration for Victims of Crime Conference, Australian Institute of Criminology in Conjunction with Victims Referral and Assistance Service Melbourne, September, 1999).

18 Christopher Bright, "PROGRAMS Victim Offender Mediation" in "VOMA Quarterly, Victim-Offender Mediation: The State of Art, (Noting the Humble beginning of Victim-Offender Mediation). Accessed June 01, 2020. http://restorativejustice.org/restorative-justice/about-restorative -justice/tutorial-intro-to-restorative-justice/lesson-3-programs/victim-offender-mediation/sthash.sd18JCpB.dpbs

19 Victoria, "Why is Victim/Offender Mediation Called Restorative Justice?"; Jan Bellard, 'Victim-Offender Mediation', The Community Mediator. Fall 2000. Accessed July 14, 2020. https://www.mediate.com/nafcm/docs/The\%20Community\%20Mediator\%20fall\%202000.pdf

20 Bright, "PROGRAMS Victim Offender Mediation"

21 Mark Umbreit, "Restorative Justice Through Victim Offender Mediation: A Multi-Site Assessment" Part 2 Western Criminology Review 1 (1)(1998) http://wcr.sonoma.edu/v1n1/umbreit.html accessed 11/12/17.

22 Mark Umbreit, Robert B. Coates, Betty Vos, “The Impact of Victim-Offender Mediation: Two Decades of Research" in Victim-Offender Mediation, Federal Probation (December, 2001) 29-35, 30
} 
offenders the opportunity to be heard on the crime in question. Here the victim would get to know the reason why the offender acted the way he or she did against the victim. The offender is also given the opportunity to know the effect of his or her conduct leading to the crime committed. VOM thus creates opportunity for victims and offenders to share consequences of crimes committed thereby mending the wounds created by the crimes committed. Negative thoughts created in the minds of victims and offenders about each other by virtue of the crimes committed are dispelled by them after undergoing a VOM process. Consequently, a victim who considered an offender a monster for having committed a crime against the victim may after undergoing the VOM process regard the offender as human and vice versa. These encounters between victims and offenders have been found to increase their satisfaction with the VOM process. ${ }^{23}$ It has been held that because of VOM's ability to increase satisfaction of both victim and offender of a crime, their satisfaction in the criminal justice system are increased compared with prosecution of criminal cases in court. ${ }^{24}$

VOM also ensures fairness in the settlement process involving a criminal case. ${ }^{25}$ In addition to the parties to VOM getting the requisite satisfaction expected from criminal prosecutions, victims and offenders who submit to VOM also come out from the process feeling that fair outcomes have been reached. Because of the way parties to VOM processes regard outcomes of VOM processes, they also tend to regard the VOM for settlement of criminal cases as a fair system. ${ }^{26}$

VOM has the tendency of ensuring restitution of victims of crime even though other remedies like performance of community service, direct service to the victim or monetary compensation are available for compensating the victim of the crime.

Further, cost of resolving a criminal case through VOM is considerably reduced compared to prosecuting criminal cases. ${ }^{27} \mathrm{VOM}$ offers time saving, cost cutting proceedings for reaching amicable settlement compared to prosecution of criminal cases in Court. Through VOM, offenders are often not handed custodial sentences thereby reducing the rate of congesting prisons. The reduction in trial time and number of incarcerations invariably translates into saving cost of prosecution to the state. ${ }^{28}$

In addition, while criminal prosecutions in courts create enmity between victims and offenders thereby marring relationships between victims and their relations and offenders and their relations, VOM has the tendency of enhancing or maintaining relationships between the victims and offenders, and their privies. This advantage of employing VOM in resolving criminal case is realized through the face-to-face encounters of victims and offenders in resolving their differences through a VOM processes in which the parties get to understand the reasons for their opponents acting the way they did and finding solutions for dealing with the injuries arising from the crime.

VOM has a positive correlation with prevention of offenders from further committing crime or being rearrested or being reconvicted for the same or similar offences. The rate at which offenders of crimes commit the same offence and are rearrested or reconvicted for the same offence is referred to as recidivism rate. As regards recidivism rate, while prosecution, conviction and punishment of offenders of crimes through the court system have been found not to prevent reoffending by these offenders of crimes, offenders who submit to VOM were found to be less likely to commit subsequent offenses. ${ }^{29}$

VOM has also been seen as a tool for diversion from the court system..$^{30}$ With the stockpile of cases in the courts, VOM serves as an important tool for diverting pending and incoming cases from the court system to enable the court free hands to handle other cases before the court. Diversion through VOM processes ensure that offenders are taken through a less time consuming, less expensive and a less severe dispute resolution process than the known time consuming, more expensive and severe court system. ${ }^{31}$ A research carried out on the usage of VOM as a tool for diversion shows that VOM has reduced trials in court by two- thirds. ${ }^{32}$

\section{Demerits of Victim-Offender Mediation in Dispute Resolution}

Aside the numerous advantages in deploying Victim-Offender Mediation (VOM) for resolving criminal cases, the processing has been criticized as having downsides. Major among these downsides is the criticism that VOM process has no established adequate guidelines to ensure the process is effect and ethical. ${ }^{33}$ It has also be argued that implementing VOM in resolving criminal cases may also led to victims being confronted with the offenders which may not provide protection for the victims where victims and offenders of crimes are referred for settlement by VOM as some victims

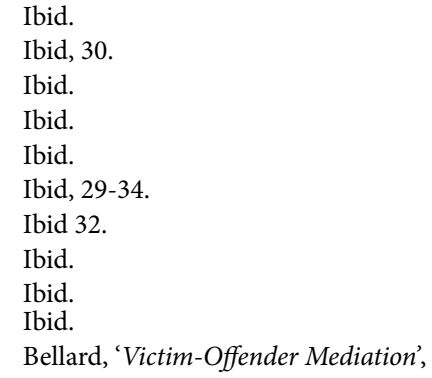


are revictimized during the VOM process. ${ }^{34}$ It is said that implementing VOM in resolving criminal cases may lead to unclear goals or policies and practices of the institution embarking on the implementation as there is insufficient foundation and training in VOM processes. ${ }^{35}$

This study seeks to ascertain whether there are justifications for implementing Victim-Offender Mediation in Ghana's criminal justice system. The guiding research question in this study is whether there are justifications for implementing Victim-Offender Mediation in Criminal Justice System of Ghana. This research question will be answered through the analysis of provisions of selected laws of Ghana. Findings of the study would provide a lead on the legal justification for Ghanaian courts and other stakeholders in the criminal justice system to VOM in resolving some criminal cases to avert most of the short falls with Ghana’s criminal justice system.

\section{Research Methods and Theoretical Method of Enquiry}

Research methods refers to the theoretical and philosophical framework for carrying out a research as well as the processes and procedures employed for the study. ${ }^{36}$ This research is grounded in the doctrinal approach to legal research. This research approach involves a careful reading and comparison of appellate opinions with the view to identifying ambiguities, exposing inconsistencies among cases and lines of cases, developing distinctions, reconciling holdings and otherwise exercising the characteristic skills of legal analysis. ${ }^{37}$ This approach to legal research is premised on the idea that law is largely an autonomous discipline hence practitioners do not have to know any other field of learning to contribute to it,$^{38}$ and that a subject properly entrusted to persons trained in law and in nothing else. ${ }^{39}$ Doctrinal analysis sometimes goes outside the logic of an opinion or series of opinions being examined by legal practitioners in making judgments but practitioners do not stray too far. This approach to legal research also involves the study of cases, experience as lawyers, common sense, and shared moral and political values of a society to evaluate the practicality and justice as distinct from the clarity and consistency of existing or proposed legal rules. Doctrinal ideology of law has been attacked by Holmes, who argues that 'law is a tool for achieving social ends, so that to understand law requires an understanding of social conditions. ${ }^{40}$ By implication, Holmes postulates that it is only when one knows something about a society that one can understand the laws in the society to be able to criticize and improve the law because law is a deliberate instrument of social control. ${ }^{41}$ Accordingly doctrinal analysis is insufficient to study and understand law in terms of how it reverberates in society. Notwithstanding, the attacks on doctrinal paradigm, it is still the dominant mode compared with other approaches to legal scholarship. ${ }^{42}$

\section{Rationale for Selecting Qualitative Research Method Using Doctrinal Approach}

The researcher's choice of a qualitative research premised on the doctrinal approach to legal research is that the data required to be collected are mainly primary data in the form of selected statutes of the Republic of Ghana. ${ }^{43}$ These primary data would have to be perused and analysed using characteristic skills of legal analysis to identify provisions in these data which provide justification for implementing VOM in resolving criminal cases in Ghana. Since qualitative research method uses smaller sample size than quantitative research method to ensure that a representative sample is used in the research $;{ }^{44}$ it would be appropriate to use this research method in analyzing the selected laws for this research. A known limitation associated with qualitative research is that there is uncertainty as to whether a clear research pattern could emerge in a qualitative research. However, given the nature of research to be conducted, that is perusing and analyzing provisions of selected statutes and literature on using ADR processes for resolving criminal cases in Ghana, a doctrinal approach to legal research is appropriate hence the legal research approach deployed in conducting this research. The research method was therefore a qualitative method one which provided comprehensive answer to the research question.

\section{Limitations of the study}

This study concentrates on ascertaining the justification for implementing VOM in the criminal justice system of Ghana

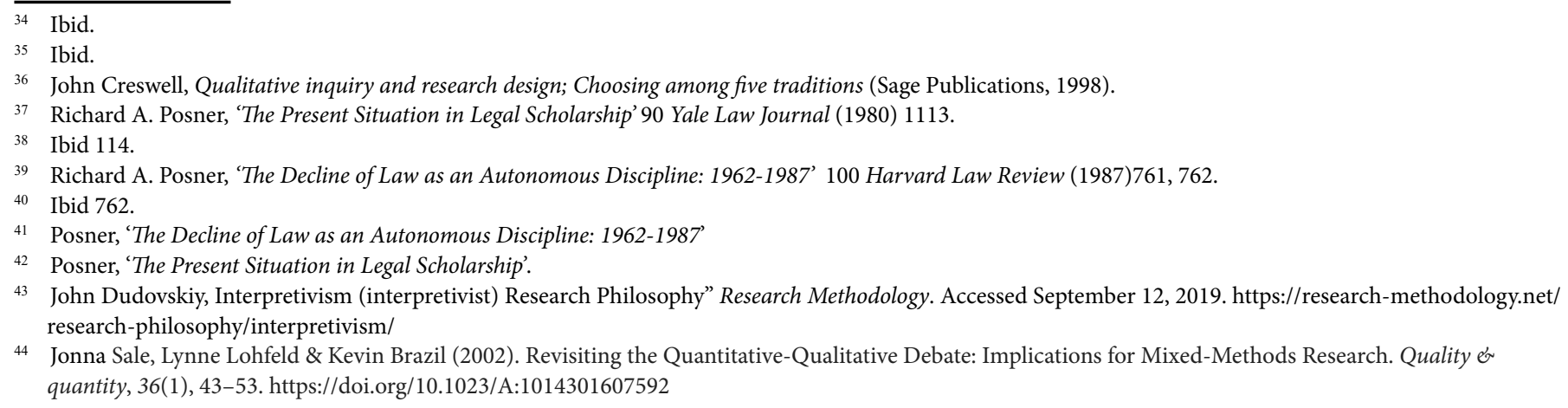


but the study is fraught with some limitations. Prime among these limitations is time constraint. Ideally, it is desired that the research is conducted perusing and analyzing most statutes of Ghana with provisions on dispute resolution but for the limited time allocated for fulfilling the objective of the research. This deprives the researcher of the possibility of analysing other laws which may provide further justification and scope for implementing VOM processes in resolving criminal cases in Ghana. However these limitations do not render the research irrelevant because the parent laws on most crimes and offences on Alternative Dispute Resolution and laws relating to courts in Ghana, composition and jurisdiction of these courts are covered under this study. The selected laws and literature on using Alternative Dispute Resolution processes for resolving criminal cases in Ghana provide a significant lead on whether or not there are justifications for implementing VOM in Ghana’s criminal justice system.

\section{Data collection}

Research data may be classified into primary and secondary data. Primary data are information collected by the researcher himself or herself for analysis in fulfilling objectives of a research. ${ }^{45}$ On the other hand, Secondary data are information from previous research works readily available for use by other researchers to achieve objectives of a research. ${ }^{46}$ Qualitative Data may be collected through conducting interviews, observing a phenomenon in a population and collection of both primary and secondary data. ${ }^{47}$ This research analyses the Courts Act 1993 (Act 459), Alternative Dispute Resolution Act2010 (Act 798), Children's Act1998 (Act 560), Ghana Domestic Violence Act 2007 (Act 732), Juvenile Justice Act 2003 (Act 653) and works of literature on the use of Alternative Dispute Resolution processes in resolving criminal cases.

\section{Data Analysis and Discussion}

This section is dedicated to analyzing the selected laws of Ghana and literature on the use of ADR processes in resolving criminal cases to ascertain whether there are adequate provisions in these laws which justify implementing VOM in the criminal justices system of Ghana.Data analysis is "a process which commences after collecting data and double checking same from the Research sample". 48

Qualitative data could be analysed using two methods by using social constructionist analysis or by using interpretative analysis. Social constructionist analysis is a method of analysing data where particular utterances, texts or events in cultural materials are revealed and analysed. ${ }^{49}$ On the other hand, Interpretative analysis is a method of analysing data which involves the description of the characteristics, processes, transactions and contexts that are related to the phenomena that are being studied." 50

\section{Legal justification for deploying Victim-Offender Mediation in the Criminal Justice System of Ghana.}

Legal regimes on application of ADR mechanisms in settling criminal case vary from one jurisdiction to another. Therefore, in ascertaining justification for the implementing VOM in settling criminal cases. In carrying out this research, where it was found that the selected laws for this research make provisions for the implementation of VOM in Ghana, the scope for implementing VOM in settling criminal cases by the provisions was also looked at.

\section{Justification for deploying VOM under the Courts Act 1993 (Act 459)}

Section 73 of the Courts Act 1993 (Act 459) provides that:

"Any court, with criminal jurisdiction may promote reconciliation, encourage and facilitate a settlement in an amicable manner of any offence not amounting to felony and not aggravated in degree, on payment of compensation or on other terms approved by the court before which the case is tried, and may during the pendency of the negotiations for a settlement stay the proceeding for a reasonable time and in the event of a settlement being effected shall dismiss the case and discharge the accused person. (emphasis supplied)"

Korang has rightly observed that not every criminal offence in Ghana may be a subject of out of court settlement. ${ }^{51}$ On his perusal of the Courts Act, Korang has also stated that sec 73 of the Act 459 ousts the jurisdiction of the court to entertain settlements arising from commission of felonious offences. It was further held that by the provision of sec 73 of Act 459 only vest the courts with power to refer a criminal case for settlement out of court and that the Attorney-General and its officers validly appointed to prosecute a criminal case are precluded from opting for settlement of criminal cases

\footnotetext{
45 Claire Bless and Craig Higson-Smith, Fundamentals of social research methods: An African perspective. (2 ${ }^{\text {nd }}$ edn. Kenwyn: Juta, 1995).

46 Ibid.

47 Dudovskiy, "Interpretivism (interpretivist) Research Philosophy" Research Methodology.

48 Ralph Taylor. Research methods in criminal justice (New York: McGraw-Hill, 1994); Aaron Labane, 'Offender Classification As A Rehabilitation Tool' (MA in the Subject Penology Thesis, University of South Africa, 2012).

49 Ibid.

50 Ibid.

51 Daniel Korang, Criminal Prosecution in Ghana: Practice and Procedure. (Kumasi: UPK Printing Press, 2017).
} 
out of court. ${ }^{52}$

These observations notwithstanding, there are other deductions that could be made from sec 73 of Act 459 . Notably among these deductions is the fact that offences not aggravated in degree can also not be referred for resolution by VOM. Offences aggravated in degree meant that if an offence committed did not fall within the categories of crimes regarded as first or Second degree felony but felonious crimes resulted from the commission of the crime, then the offence which was not in itself felonious would be deemed to aggravate in degree. In such cases, a court will not rely on an aspect of the offence committed which is not felonious in nature to refer the matter for resolution by VOM.

Examples of offences commission of which the court could refer the victim and the offender for settlement by VOM are concealment of body of a child, ${ }^{53}$ exposing a child to danger ${ }^{54}$ negligently causing harm, ${ }^{55}$ threat of harm, ${ }^{56}$ assault,${ }^{57}$ cruel practices in relation to bereaved spouses, ${ }^{58}$ abduction of child under eighteen, ${ }^{59}$ indecent assault, ${ }^{60}$ procuration, ${ }^{61}$ seduction or prostitution of a child under sixteen, ${ }^{62}$ compulsion of marriage,${ }^{63}$ negligent and intentional libel,${ }^{64}$ improper removal of or dealing with stamps as an employee of Posts and Telecommunications Department, ${ }^{65}$ and taking or administering unlawful oath. ${ }^{66}$

Furthermore, where the court is satisfied that a criminal case before it ought to be settled out of court, the provision empowers the court to stay proceedings pending settlement and refer the matter for settlement. When settlement is reached between the parties, the court needs no authorization from the Attorney-General or its officers acting as prosecutor to dismiss the case and discharge the accused person. This provision seems to have ousted the prosecutorial powers of the Attorney-General or its officers responsible for prosecution to decide which case they would prosecute to conclusion and the ones nolle prosequi could be entered.

The provision tends to exclude the state from participating in the settlement process and affords the victim of a crime and the accused person the opportunity to meet face-to-face to settle their differences and arrive at their own terms of settlement. Again, the provision provides for reconciliation and compensation or restitution of the victim as it provides for payment of compensation or fulfillment of certain terms approved by the court before which the case is tried.

Section 73 of Act 459 further tends to suggest that settlement could be permitted before close of trial and after conviction hence any settlement made under it may be between a victim and an accused or between a victim and a convict/offender.

The 1992 Constitution of the Republic of Ghana provides that a person charged with a criminal offence should be presumed innocent until proven guilty or when the accused pleads guilty. ${ }^{67}$ This constitutional provision and Sec 73 of Act 459 with the understanding of the definition of VOM raises controversy as to whether VOM could be deployed in criminal cases before an accused person in Ghana is convicted of a crime. This is because under Article 19 (2) (c) of the 1992 Constitution of the Republic of Ghana, it is only after full trial or upon pleading guilty to a crime that a person could be deemed to be guilty of the crime and hence can be deemed to be an offender in Ghana. That being the case, the aspect of provisions of Sec 73 of Act 459 which can be construed as permitting out-of-court settlement after conviction of the accused person is what can serve as one of the justifications for implementing VOM in Ghana.

\section{Justification for deploying VOM under the Alternative Dispute Resolution Act 2010 (Act 798)}

Korang identifies the Act 798 (hereinafter called ADR Act) as providing for VOM, citing sections 64 (1) and 89 (2) of the Act which provides for mediation and Customary Arbitration to support of his claim. ${ }^{68}$ It is argued that even though section 64 (1) of the ADR Act has a link with VOM, section 89 (2) of the ADR Act which touches on Customary Arbitration is not a provision on VOM.

A closer reading of the ADR Act reveals that Ghanaian courts have been empowered to explore alternative dispute

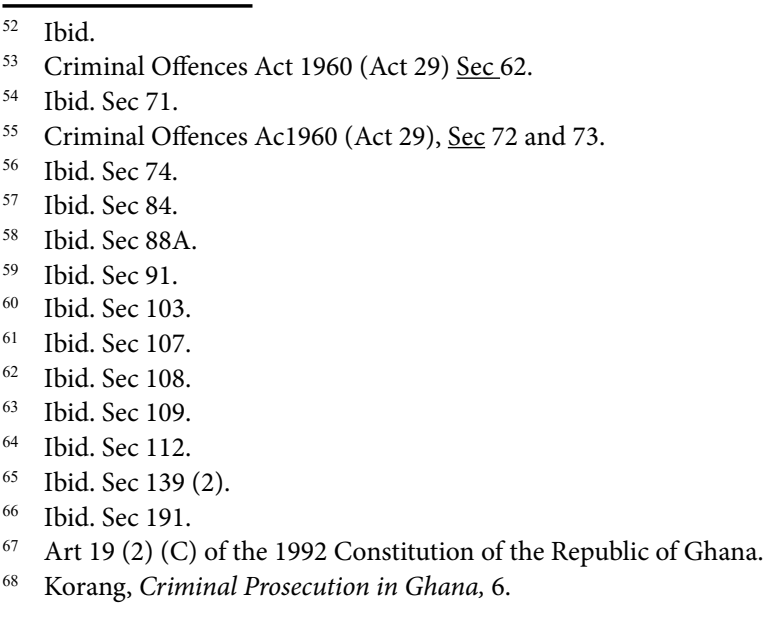


settlement processes in some criminal cases. The Act for instance precludes any person from resolving any matter related to the national or public interest; the environment; the enforcement and interpretation of the Constitution; or any other matter that by law cannot be settled by an alternative dispute resolution method from being resolved by any ADR process recognized under the Act (emphasis supplied) ${ }^{69}$ This means that where a matter comes before any Court of competent jurisdiction, the Court would not be clothe with jurisdiction to refer the matter for settlement by any ADR process if the matter is of public interest or touches on; environmental issues or enforcement and interpretation of the Constitution or prohibited by an enactment from being settled by ADR process. The Act also by necessary implication affirms limitations set by provisions of other enactments on resolving criminal cases by ADR processes. For instance this provision by necessary implication affirms provision in section 73 of the Courts Act1993 (Act 459) and limitations set in it in handling criminal cases. Following from the earlier discussion on section 73 of Act 459, it is argued that section 1 of the ADR Act also serves as a justification for deploying VOM in resolving certain criminal cases.

Section 64 of the ADR Act provides as follows:

1. A court before which an action is pending may at any stage in the proceedings, if it is of the view that mediation will facilitate the resolution of the matter or a part of the matter in dispute, refer the matter or that part of the matter to mediation (emphasis supplied).

2. A party to an action before a court may, with the agreement of the other party and at any time before final judgment is given, apply to the court on notice to have the whole action or part of the action referred to mediation.

3. A reference under subsections (1) or (2) shall state (a) the nature of the dispute; (b) the monetary value of the claim, if any.

4. The reasons for the reference; and (d) the remedy sought and shall have attached copies of the pleadings and any other documents the court considers relevant.

5. A reference under this section shall serve as a stay of proceedings of the court action.

6. Where a reference leads to settlement of the dispute or part of the dispute the settlement shall be (a) drawn up and filed in the court; (b) recorded by the court as a judgment of the court; and (c) enforced by the court as its judgment.

7. Where the reference does not lead to a settlement, the court shall continue with the proceedings from the point where the reference was made.

8. A reference by a court shall specify the time within which a report on the reference shall be submitted to the court.

From the foregoing provisions, it is argued that section 64 of the ADR Act (Act 798) also serves as a justification for the deployment of VOM in resolving criminal matters. Like the provisions of sec 73 of Act 459, the court is expressly empowered by the section 64 of Act 798 to refer a criminal case for resolution by mediation. The power to exercise the mandate under section 64 application of section 64 of Act 798 is also subject to section 1 of the ADR Act where the Court believes the case could be settled by Mediation at any stage criminal proceedings. Proceedings of court have been defined as all acts and events including the regular and orderly progression of a lawsuit between the time of commencement and the entry of judgment. ${ }^{70}$ This suggests that mediation could be held for a victim of a crime and the accused even though the guilt of the accused has not been determined. The foregoing provision of the ADR Act also suggests that mediation could be held between a victim, of a crime and an offender whose guilt has been determined in compliance with Art 19 (2) (c) as discussed earlier, but has not been sentenced. Further, section 64 of the ADR Act also empowers the prosecution and the accused in a case to apply to the court, on notice to the other parties, for the criminal matter to be referred for settlement by mediation. This provision also serves as an improvement on section 73 of the Courts Act, 1993 (Act 459), unlike section 73 of the Act 459, any party to a criminal case - the accused or the prosecution - is empowered to apply to the court for a criminal matter to be settled by mediation. ${ }^{71}$ However, the mediation process anticipated under the sec 64 (2) of Act 798 cannot be said to include VOM as by the provision, reference to mediation ought to be made before delivery of judgment. This suggests that the accused ought not to be proven guilty of an offence before any party to the criminal case could apply for the matter to be referred for settlement by mediation.

\footnotetext{
Alternative Dispute Resolution Act, 2010 (Act 798), Sec 1.

Black Law Dictionary (9th ed.).

Alternative Dispute Resolution Act, 2010 (Act 798), Sec 64 (2).
} 
Justification for deploying VOM under the Children's Act 1998 (Act 560) as amended by the Children's (Amendment) Act 2016 (Act 937)

Korang has also observed that the Act 560, as amended, has empowered a Child Panel to deploy VOM in criminal matters involving a child where the offence involved is minor. He further recounts provisions on the roles played by the Child Panel in the mediation process. ${ }^{72}$ A close look at Act 560 as amended revealed that the Act empowers District Assemblies in Ghana to establish child panels in each district in Ghana. ${ }^{73}$ These established child panels are tasked with the function of assisting in the resolution of criminal and civil matters concerning a child by mediation. ${ }^{74}$

Section 32 of the Children's Act 1998 (Act 560) as amended also provides that:

1. A child panel shall assist in victim-offender mediation in minor criminal matters involving a child where the circumstances of the offence are not aggravated.

2. A child panel shall seek to facilitate reconciliation between the child and a person offended by the action of the child (emphasis supplied).

3. A child appearing before a child panel shall be cautioned as to the implications of the child's action and that similar behaviour may subject the child to the juvenile justice system.

4. A child panel may decide to impose a community guidance order on a child with the consent of the parties concerned in the matter (emphasis supplied).

5. A community guidance order means placing the child under the guidance and supervision of a person of good standing in the local community for a period not exceeding six months for purposes of reform.

6. A child panel may in the course of mediation propose an apology or restitution to the offended person (emphasis supplied).

The provisions of sec 32 (1) of Act 560 expressly provides for the use of Victim-Offender mediation in minor criminal matters involving children. Therefore the combined effect of sections 28 and 32 of the Children's Act 1998 (Act 560) can be said to be justification for resolving criminal cases by Victim-Offender Mediation (VOM) in Ghana. These provisions are also in consonance with section 73 of the Courts Act 1993 and section 1 of the ADR Act 2010 as earlier discussed.

\section{Justification for Deploying VOM under the Ghana Domestic Violence Act, 2007, (Act 732)}

Section 24 of Ghana Domestic Violence Act provides that:

1. Despite section 22, if in a criminal trial in respect of domestic violence which is not aggravated or does not require a sentence that is more than two years,

a. the complainant expresses the desire to have the matter settled out of Court, the Court shall refer the case for settlement by an alternative dispute resolution method, or

b. the Court is of the opinion that the case can be amicably settled, the Court may with the consent of the complainant refer the case for settlement by an alternative dispute resolution method.

2. Where a case is referred for settlement, the Court shall in addition: (a) refer the complainant and the accused for counselling, (b) where necessary, require the accused to receive psychiatric help, or (c) in consultation with the Department of Social Welfare appoint a probation officer to observe and report on the subsequent conduct of the accused to the Court.

3. Where a probation officer appointed under subsection (2) reports that the accused has engaged in any act of domestic violence after the settlement, the accused shall be brought before the Court and prosecuted under section 22. (Emphasis supplied).

In construing section 24 (1) and (2) of Act 732 particularly the requirement that the Court should in addition refer the complainant and the accused for counseling and where necessary require the accused to receive psychiatric help or in consultation with the Department of Social Welfare the Court should appoint a probation officer to observe and report on the subsequent conduct of the accused to the Court, the said provisions suggest that the accused person referred to settlement by an alternative dispute resolution method with the complainant should have been found to be the offender. The settlement could be carried out using any of the Alternative Dispute Resolution processes with the exception of VOM which will required a conviction of an accused person before settlement is commenced.

The provisions of section 24 (1) and (2) of Act 732 empower the victim to opt for settlement out of court or for the court to refer the matter to be resolved out of court. These provisions therefore enable victims of crimes to participate in adjudication processes and also cater for the needs of both victim and offender of crime in the category of domestic violence.

\footnotetext{
72 Korang, Criminal Prosecution in Ghana, 6.

73 Children's Act, 1998 (Act 560), Sec 27.

74 Ibid, Sec 28
} 
However, section 24 (1) and (2) of Act 732 limits the submission of only domestic violence offences which are not aggravated or do not attract punishments exceeding two (2) years. This suggests that unlike the other laws referred to as justifying the use of VOM in resolving criminal cases in Ghana, misdemeanors which would attract punishment exceeding two (2) years and all crimes which are felonies or aggravated cannot be resolved under Act 732 using VOM or other Alternative Dispute Resolution process. There the provisions of section 24 (1) and (2) of Act 732 do not provide justification for the use of VOM in resolving criminal cases in Ghana.

\section{Justification for Deploying VOM under the Juvenile Justice Act 2007 (Act 732)}

Section 25 of the Juvenile Justice Ac, 2007 (Act 732) provides that:

1. After consideration of the social enquiry report, the juvenile court shall decide whether the juvenile charged with an offence should be diverted from the criminal justice system with or without conditions.

2. Diversion shall not be permitted for serious offences (emphasis supplied) Section 60 (1) of the Juvenile Justice Act defined diversion as the referral of cases of children alleged to commit offences away from the criminal justice system with or without conditions.

Sections 25 and 60(1) of the Juvenile Justice Act seek to empower a juvenile court to refer a case out of court for settlement with or without conditions. Further, from the definition of the concept of diversion, it is only alleged offenders who could have access to diversion programmes as could be gleaned from the definition section of the Juvenile Justice Act. ${ }^{75}$ Children who are alleged to have committed offences in the category of serious offences are not entitled to have access to diversion programmes. These suggest that children who have been convicted for committing crimes in the category of serious offences are also not entitled to have access to diversion programmes. From the definition of diversion provided in section 60 of the Juvenile Justice Act, diversion is an alternative dispute resolution mechanism that could be used to resolve criminal cases. Like all other ADR mechanisms and in addition to the restriction that children alleged to have committed crimes in the category of serious offences for diversion programmes, the fetters placed on categories of offences which cannot be resolved under the Alternative Dispute Resolution Act 2010 (Act 798) and the Courts Act 1993 (Act 459) discussed earlier in this article still apply.

The provisions of the Juvenile Justice Act does not restrict referring criminal case in the category of minor offences to diversion programmes. Section 60 (1) of the Juvenile Justice Act defines a minor offence as a criminal matter such as petty theft, petty assault and threatening offences. It is argued, from the definition of minor offence, that what is referred to petty theft and petty assault if looked at from the perspective of the Criminal Offences Act 1960 (Act 29) could be equated to crimes of stealing and assault respectfully which are not regarded as minor by the Act. Therefore, what constitutes petty theft and petty assault is relative and depends on the prosecutor preferring the charge against the accused persons. This is because a prosecutor who is seized with the conduct of a criminal case could prefer a charge of stealing or assault against a juvenile instead of a charge of petty theft or petty assault respectively and based on the charge preferred against the juvenile, the juvenile may or may not be diverted from the criminal justice system.

From the tenor of Section 60 (1) of the Juvenile Justice read together with Section 32 of the Children's Act, 1998 (Act 560) already touched on in this article, there is room for deploying ADR processes to resolve disputes between a Juvenile offender and his or her victim where a minor offence has been committed. Further, section 26 of the Juvenile Justice Act provides that:

1. The purpose of diversion is to

a. encourage the juvenile to be accountable for harm caused;

b. promote an individual response to the harm caused which is appropriate and proportionate to the circumstances of harm caused;

c. promote the reintegration of the juvenile into the family and community;

d. provide an opportunity to the person or community affected by the harm caused, to express their views on the impact of the harm;

e. encourage restitution of a specified object or symbolic restitution;

f. promote reconciliation between the juvenile and the person or community affected by the harm caused;

g. prevent stigmatisation of the juvenile which may occur through contact with the criminal justice system.

2. A juvenile shall not be discriminated against in the selection of a diversion programme and juveniles shall have equal access to diversion options.

3. Inhuman or degrading treatment shall not form part of the diversion programme."

\footnotetext{
75 Juvenile Justice Act, 2007 (Act 732), Sec 60 (1).
} 
From the purpose of diversion enumerated above, it appears the purpose of diversion programmes are similar to that of VOM which are discernable from the merits of VOM earlier enumerated in this article. The tenor of section 26 (1)(a), (c), (d) and (f) of the Juvenile Justice Act also suggests that a juvenile referred to diversion programmes has not been convicted for the offence for which he or she is charged. However, the court is vested with the authority to find that the juvenile must have committed the offence complained of before the purpose stated under section (1) (a), (c), (d) and (f) of the Juvenile Justice Act can be achieved. It therefore suggests that a juvenile referred to diversion programme must be found by the court to be the offender of a crime before that juvenile can have access to a diversion programme.

Section 27 of the Juvenile Justice Act also makes provision for minimum standard of diversion in the following terms. A diversion programme shall:

1. promote the dignity and wellbeing of the juvenile and the development of self-esteem and ability to contribute to society,

2. not be exploitative, harmful or hazardous to the physical and mental health of the juvenile,

3. be appropriate according to the age and maturity of the juvenile,

4. not interfere with the schooling of a juvenile, and

5. give useful skills to the juvenile where possible.

The minimum standard for diversion is in line with the goals of VOM which are discernable from the merits of deploying VOM recounted earlier in this article. From the earlier discussions on the provisions of the Juvenile Justice Act, it can be inferred that even though children alleged to have committed offences not in the category of serious offence could be referred to diversion programmes, the provisions provide justification for deploying and ADR process in the criminal justice system of Ghana.

\section{The Concept of 'Mediability' Deducible from Justifications for Deploying Victim-Offender Mediation in Criminal Justice System of Ghana}

The provisions so far discussed under justifications for deploying VOM defined the parameters for which VOM and other mediation processes could be deployed in resolving criminal cases thereby placing bars on certain classes of criminal cases from being resolved through VOM and other mediation processes. Like the legal concept of arbitrability in arbitration in which disputes of certain classes are barred from arbitration by domestic laws or decisions of the courts, the concept of 'mediability' could also be coined out as deducible from the provisions on justification for deploying VOM so far looked at. The concept of 'mediability' would mean bars on resolving certain classes of crimes in mediation. Therefore, from perusing the subchapters on justification for deploying VOM in the criminal justice system of Ghana, sections 1 and 64 of the Alternative Dispute Resolution Act2010 (Act 798), section 32 of the Children's Act 1998 (Act 560), and section 73 of the Courts Acts 1993 (Act 459) are examples of laws which provide bars on resolving certain classes of crimes by mediation and for that matter by VOM in Ghana.

\section{Summary of Findings}

The analysis on the Courts Act 1993 (Act 459), Alternative Dispute Resolution Act 2010 (Act 798), Children's Act 1998 (Act 560), Ghana Domestic Violence Act 2007 (Act 732) and Juvenile Justice Act 2003 (Act 653) in relation to the justifications for implementing VOM in Ghana's criminal Justice System of Ghana reveals that they provide justifications for implementing VOM. It was also found that only offences in the categories of misdemeanor which are not aggravated in degree and offences regarded as minor offences can be referred to settlement by VOM. Finally, criminal cases involving matters of public interest, and those affecting the environment cannot be resolved using VOM.

\section{RECOMMENDATIONS}

The following recommendations are made for consideration by stakeholders in the criminal justice system of Ghana:

1. The courts should take advantage of legal provisions that support the use of the VOM in resolving criminal cases in Ghana in order to forestall further incursion of the shortfalls identified in the Criminal Justice System of Ghana.

2. The Judicial service should liaise with institutions with expertise in VOM to provide training in the area of the VOM to enhance capacities of all stakeholders in implementing the VOM models in the criminal justice system of Ghana.

3. Sensitization of Ghanaians on the mechanics of VOM in dispute resolution in criminal cases is also necessary to create awareness among the populace so that reference of criminal cases for settlement by VOM will not appear to them as compromising the criminal justice system to generate any mistrust for the justice system. 


\section{CONCLUSION}

The research ascertained the justification for implementing Victim-Offender Mediation (VOM) in the criminal JusticeSystem of Ghana. It reviewed selected enactments which are applicable to the criminal justice system and works of literature from legal text writers to ascertain whether there are justifications for implementing Victim-Offender Mediation in the criminal Justice System. The findings from this research and works of literature revealed that Courts Act 1993 (Act 459), Alternative Dispute Resolution Act 2010 (Act 798), Children's Act 1998 (Act 560), and Juvenile Justice Act 2003 (Act 653) provide justification for implementing Victim-Offender Mediation (VOM) in the criminal Justice System of Ghana. This findings provides adjudicators and relevant stakeholders in the criminal Justice System of Ghana the bases for including Victim-Offender Mediation (VOM) in the list of dispute resolution processes to which criminal cases referred for out of Court settlement are admitted to.

\section{ABOUT AUTHOR}

Enoch Kwabena Amoah Esq., is an Assistant Lecturer at the Faculty of Law of Kwame Nkrumah University of Science and Technology, Kumasi, Ghana and Adjunct Lecturer at the Faculty of Law of Wisconsin International University College, Feyiase, Ghana. He holds a Master of Laws degree and is also a Barrister and Solicitor of Law in the Republic of Ghana. He is an associate of Minkah-Premo \& Co. legal firm in Kumasi, Ghana and a Chief of Ekumfi Akwakrom in the Central Region of the Republic of Ghana with stool name NANA AKWA III.

\section{BIBLIOGRAPHY}

\section{Constitution and Statutes:}

The 1992 Constitution of the Republic of Ghana.

Alternative Dispute Resolution Act 2010 (Act 798).

Children's Act 1998 (Act 560).

Courts Act 1993 (Act 459).

Criminal Offences Act 1960 (Act 29).

Juvenile Justice Act 2007 (Act 732).

\section{Cases:}

Eric Asante v. The Republic, CRIMINAL APPEAL NO. J3/7/2013 (SC, 2017).

Frimpong v. Republic [2013] 42 M.L.R. 1.

Articles, Books and Other Literature:

Agyemfra, Emmanuel. "Ghana Prisons Service Council unveils 2015/2016 Annual Report on Project Efiase”, Ghana Web. September 6, 2016. Accessed November 11, 2017. https://www.ghanaweb.com/GhanaHomePage/NewsArchive/Ghana-Prisons-Service-Council-unveils-2015-2016-Annual-Report-on-Project-Efiase- 467743

Ames, Jessica C. Restorative Justice: Including Victims, Offenders and Communities in Criminal Justice Dialogue (Smith College, 2007).

Ansah, Marian Efe. "Help Decongest Prisons-CJ to Judges", Citifmonline.Com, February 23, 2015. Accessed March 07, 2020. http://citifmonline.com/2015/02/23/help-decongest-prisons-cj-to-judges/\#sthash. wV51iCOp.dpuf.

Bellard Jan, 'Victim-Offender Mediation', The Community Mediator. Fall 2000. Accessed July 14,2020. https://www.mediate.com/nafcm/docs/The\%20Community\%20Mediator\%20fall\%202000.pdf

Carmel Benjamin A. M. Victoria, "Why is Victim/Offender Mediation Called Restorative Justice?" (A paper presented at the Restoration for Victims of Crime Conference, Australian Institute of Criminology in Conjunction with Vic tims Referral and Assistance Service Melbourne, September, 1999).

Bless C. and Higson-Smith C., Fundamentals of social research methods: An African perspective. $2^{\text {nd }}$ ed.Kenwyn: Juta, 1995.

Bright, Christopher. "PROGRAMS Victim Offender Mediation" in "VOMA Quarterly, Victim-Offender Mediation: The State of Art, (Noting the Humble beginning of Victim-Offender Mediation.)" Accessed December 12, 2018. http://www.vorp.com/articles/art.html

Creswell, J.W. Qualitative inquiry and research design; Choosing among five traditions. Sage Publications, 1998. 
Dudovskiy, J., "Interpretivism (interpretivist) Research Philosophy” Research Methodology. Accessed

September 12, 2017. https://research-methodology.net/research-philosophy/interpretivism/

Garner, Bryan A. (ed.), Black Law Dictionary (9th ed.).

Ghana Prisons Service, "Inmate Statistics." Accessed November 11, 2017.

www.ghanaprisons.gov.gh/statistics.html.

Korang, Daniel, Criminal Prosecution in Ghana: Practice and Procedure (UPK Printing Press, Kumasi 2017) 645 - 121.

Labane, Aaron. 'Offender Classification as a Rehabilitation Tool' (MA in the Subject Penology Thesis, University of South Africa, 2012), 339-14.

POS FOUNDATION, "Justice for all programme for Remand Prisoners." Accessed July 14, 2016. http://posfoundation.org/justice-for-all-programme-for-remand-prisoners/

Posner R. A., “The Decline of Law as an Autonomous Discipline: 1962-1987” 100 Harvard Law Review (1987): 761, 762. https://doi.org/10.2307/1341093

"The Present Situation in Legal Scholarship" 90 Yale Law Journal (1980): 1113.

Sale, J. E., Lohfeld, L. H., \& Brazil, K. (2002). Revisiting the Quantitative-Qualitative Debate: Implications for MixedMethods Research. Quality \& quantity, 36(1), 43-53. https://doi.org/10.1023/A:1014301607592

Taylor R.B., Research methods in criminal justice (1994, McGraw-Hill, New York).

Umbreit, Mark, Coates, Robert B., Vos, Betty. "The Impact of Victim-Offender Mediation: Two Decades of Research", Victim-Offender Mediation, Federal Probation, December, 2001.

. "Victim-Offender Mediation and Dialogue" in Dialogue-Driven Victim-Offender Mediation Training Manual A Composite Collection of Training Resource Materials.

Umbreit, Mark. "Restorative Justice Through Victim Offender Mediation: A Multi-Site Assessment" Part 2 Western Criminology Review 1 (1) (1998). Accessed November, 2017. 